\title{
Sobre as origens e motivações do Ato Institucional 5
}

About the Origins and Motivations

of the Institutional Act 5

Rodrigo Patto Sá Motta*

\section{Resumo}

$\mathrm{O}$ artigo consiste em proposta analítica/ interpretativa sobre as motivações dos atores responsáveis pela edição do Ato Institucional 5, em dezembro de 1968, que significou um aprofundamento e radicalização da ditadura militar instaurada em 1964 no Brasil. Com base no estudo de fontes secundárias e primárias, neste caso documentos diplomáticos norte-americanos em grande parte inéditos, o texto pretende revisitar o problema das origens do AI-5 para construir análise dedicada à compreensão e explicação do fenômeno. A principal conclusão é que o novo ato autoritário se prestava não apenas a intensificar a repressão sobre a esquerda, mas, sobretudo, para enquadrar os dissidentes nas próprias hostes da ditadura.

Palavras-chave: AI-5; 1968; ditadura; direita.

\section{Abstract}

The article is an analytical/interpretive proposal on the motivations of the actors responsible for the Institutional Act 5 (December 1968), which meant a radicalization of the military dictatorship established in 1964 in Brazil. Based on secondary and primary sources, in this case largely unpublished US diplomatic documents, the text intends to revisit the problem of the origins of the AI-5 aiming to construct an analysis dedicated to understand and explain the phenomenon. The main conclusion is that the new authoritarian act intended not only to intensify repression targeting the left-wing forces but, above all, to contain dissidents among the original supporters of the dictatorship.

Keywords: AI-5; 1968; dictatorship; right-wing.

\footnotetext{
* Universidade Federal de Minas Gerais (UFMG), Departamento de História. Belo Horizonte, MG, Brasil.rodrigopsamotta@gmail.com <https://orcid.org/0000-0003-0158-6501>
} 
Em período recente, parcela expressiva da historiografia tendeu a perder o interesse pelo estudo das motivações e das origens dos fenômenos políticos. Entretanto, especialmente no campo da história política, continua fundamental tentar compreender as escolhas dos agentes, bem como os motivos que os levam à ação. E não apenas para alcançar melhor conhecimento sobre eventos e processos históricos, mas, também, devido à eventual utilidade para nossas escolhas e dilemas presentes. No caso brasileiro, em especial, saber por que agentes autoritários decidem golpear as instituições e instalar mecanismos ditatoriais tem importância significativa para quem aposta na democracia. Essa introdução serve para explicar a própria motivação que leva a revisitar a crise de 1968 e buscar quadro compreensivo/explicativo ${ }^{1}$ mais satisfatório para entender as origens do AI-5. Embora o tema tenha sido objeto de estudos tanto da ciência política como da historiografia, acreditamos que vale a pena investir mais em sua análise, até porque se trata de explorar caminhos menos visitados pela literatura acadêmica. Reside aí a pretensão deste texto, que representa a continuação e o aprofundamento de uma análise sobre as origens do AI-5 publicada em outro trabalho (cf. Motta, 2014, p.148-151).

O impacto do AI-5 na história brasileira é bem conhecido, mas não custa reiterar alguns pontos básicos. Para além da imagem corrente de "golpe dentro do golpe", o mais significativo é que ele representou um aprofundamento da ditadura, ou da "revolução" como diziam seus apoiadores (sem aspas, no seu caso). O novo instrumento autoritário armou o Estado de poderes extraordinários, tal como o primeiro AI, editado em 1964. No entanto, diferente do primeiro Ato, o AI-5 não tinha prazo de expiração e poderia abrir caminho para ditadura eterna dos militares.

A propósito, o debate historiográfico sobre a melhor adjetivação para a ditadura (militar, civil-militar ou militar-civil) perde intensidade quando está em foco a fase pós-AI-5, já que o novo ato significou o afastamento dos militares em relação a uma parte de seus aliados civis de inclinação moderada ou liberal. Por exemplo a grande imprensa, apoiadora - e instigadora - entusiasta da intervenção de 1964, quanto ao AI-5 teve uma atitude fria, mostrando uma discordância que nem a censura conseguiu abafar inteiramente. O mesmo ocorreu com outro aliado fundamental de 1964, o governo norte-americano, que discordou do novo Ato e reduziu seu apoio à ditadura, ao menos no primeiro momento. Em suma, após o fatídico 13 de dezembro de 1968 a ditadura se tornou mais militar, mais autoritária, e reduziu o espaço para a atuação de aliados civis, embora estes continuassem presentes, só que agora em posição ainda mais subalterna. O partido oficial, a Arena, tornou-se 
menos relevante nos assuntos do governo, que tratou com desdém os seus quadros políticos ao ponto de escolher técnicos e lideranças jovens para cargos de responsabilidade.

Evidentemente, outro aspecto chave na caracterização do AI-5 como um marco é a violência repressiva, que aumentou exponencialmente após dezembro de 1968, como é visível nos registros de mortos, torturados, desaparecidos etc. Claro que o incremento da violência tem relação também com o ativismo da oposição armada, cujas ações tornaram-se mais agudas e encontraram resposta violenta do Estado. Porém, a responsabilidade pelo aumento da repressão não pode ser imputada às suas vítimas. A maré montante da repressão estatal decorreu do surgimento de um marco institucional que estimulava os agentes públicos à violência. Pode-se dizer que o novo Ato Institucional liberou as feras, que saíram à caça (e à cassa) com apetite ainda maior do que em 1964.

Mas o AI-5 significou um marco também no que se refere aos projetos modernizadores da ditadura. Muitas ações vinham sendo planejadas desde 1964, mas o ritmo de sua implantação se acelerou graças ao aumento de prerrogativas do poder central, que passou a ter meios para fazê-lo de maneira autoritária, sem considerar a opinião de políticos e outras lideranças. O contexto do AI-5 significou o ápice do projeto modernizador-autoritário da ditadura, fase em que os tecnocratas civis e militares tiveram mãos livres para agir, de maneira semelhante aos "técnicos" que operavam os aparelhos de repressão.

Como se sabe, o fato detonador do AI-5 foi a derrota do pedido do governo à Câmara dos Deputados para punição do parlamentar Márcio Moreira Alves. Outra razão apresentada por fontes militares foi a necessidade de poderes extraordinários para reprimir as organizações de esquerda armada, os "terroristas" como eram chamados pelo governo e a grande imprensa. No entanto, tais motivos sempre foram objeto de dúvida e questionamento, mesmo à época, pois grupos e lideranças que vinham apoiando a ditadura não acharam convincentes as justificativas para o AI-5. Ao contrário da intervenção autoritária de 1964, que contou com amplo apoio nas classes médias e superiores, a edição do AI-5 gerou menos simpatia.

Há muito existem dúvidas acerca dos reais motivos por trás da decretação do quinto Ato Institucional da ditadura, que são alimentadas por depoimentos de atores contemporâneos apontando para uma trama farsesca. Por exemplo, Delfim Netto, ministro presente à reunião que decretou o AI-5, afirmou que o caso Moreira Alves foi apenas uma desculpa (apud Gaspari, 2002, p.339). Mas afinal, por quê? Se a derrota do governo Costa e Silva na Câmara dos Deputados na célebre votação de 12 de dezembro de 1968 foi mera desculpa 
para o AI-5, qual foi a motivação real? Com base em análise de fontes secundárias e primárias, algumas delas inéditas, tentaremos responder a essas perguntas. Sobretudo, a intenção é oferecer uma interpretação mais atenta aos valores e aos objetivos dos grupos de direita ocupantes do poder estatal.

\section{BREVE SÍNTESE DOS EVENTOS}

Para além do seu significado político, 1968 pode ser considerado um marco do alardeado "milagre econômico" da ditadura, pois o PIB registrou alta de aproximadamente $10 \%$ naquele ano. A estratégia expansionista do ministro Delfim Netto, que ascendeu ao comando econômico em 1967 com o segundo presidente militar, Costa e Silva, começara a mostrar sinais positivos. No entanto, os contemporâneos não perceberam o começo do ciclo econômico expansionista, seja porque seus efeitos ainda eram limitados, seja porque prestaram mais atenção ao quadro político. Trata-se de uma constatação para reforçar a interpretação de que a crise de 1968 teve raízes marcadamente políticas.

No início de 1967, o general Costa e Silva assumiu o governo com a promessa de continuar a obra da "revolução", mas, também, trazia na bagagem alguns planos de ajuste. Além de redirecionar a economia rumo a um crescimento mais acelerado, afastando-se um pouco dos postulados econômicos liberais da gestão de Castelo Branco, que se preocupou mais em sanear as finanças e conter a inflação, o segundo governo militar trazia algumas novidades na área política. Ministro da Guerra de Castelo Branco, Costa e Silva assumiu a posição de liderança dos setores militares radicais que desejavam o aprofundamento da "revolução". Eles criticavam Castelo Branco por considerá-lo moderado, às vezes, no tratamento dos "inimigos da revolução", mas, também, por descuidar dos interesses nacionais ao privilegiar uma pauta econômica liberal. Com apoio da direita militar e civil, Costa e Silva se impôs como candidato à sucessão presidencial, a contragosto de muitos líderes do movimento de 1964, que o consideravam oportunista e despreparado para o cargo. Os diplomatas norte-americanos, por exemplo, o viram com maus olhos e, alimentados por suas fontes de informação no Brasil, consideraram um equívoco colocá-lo em cargo tão importante. ${ }^{2}$

Entretanto, Costa e Silva assumiu a presidência com discurso talhado para desarmar os seus críticos, prometendo diálogo e tolerância com a oposição. Uma atitude estranha para quem se apoiava na direita militar, porém, compreensível em vista da estratégia de reduzir o mal-estar nos círculos liberais ${ }^{3}$ 
apoiadores da ditadura. Além disso, Costa e Silva não era pessoalmente radical, apenas se ligara a tais grupos para abrir caminho ao poder. Por sua vez, a estratégia de impulsionar o crescimento econômico e a atitude de aparente moderação política visavam melhorar a imagem da "revolução", que perdera popularidade durante os austeros anos de Castelo Branco, marcados pela recessão e o arrocho salarial. Mas por trás da fachada tolerante e dos discursos moderados a máquina repressiva e a direita militar radical estavam a postos, em guarda. Logo seriam chamadas à ação.

Costa e Silva assumiu o governo em contexto de tentativa de legitimar e estabilizar a ditadura, tendo como marco a entrada em vigor da Constituição (de 1967) aprovada pelo governo anterior. Era um regime autoritário, sem dúvida, que dispunha de muitos instrumentos repressivos, como a Lei de Segurança Nacional e a Lei de Imprensa, para não falar nos aparatos de informações e de repressão criados ou reformulados desde 1964, como o Sistema Nacional de Informações (SNI) e o Centro de Informações do Exército (CIE). No entanto, o novo presidente não dispunha dos mesmos poderes excepcionais de seu antecessor, como a possibilidade de cassar mandatos parlamentares, e tinha de respeitar certos espaços liberais concedidos à oposição e à imprensa. O fato é que, a partir de 1967, as forças de oposição perceberam um horizonte menos nebuloso e a existência de condições melhores para agir e testar os limites da tolerância oficial. Significativamente, entre 1967 e 1968 alguns exilados voltaram ao país, movidos pela esperança de refazer suas vidas ou pela crença de que a ditadura poderia ser derrotada. Nesse sentido, no governo Costa e Silva a insatisfação acumulada contra a ditadura desde 1964 encontrou quadro mais favorável para exprimir-se, para extravasar.

É certo que a oposição se fez presente desde o princípio da ditadura, porém, a intensidade da resistência ao poder autoritário aumentou entre 1967 e 1968, tendo como marcos principais o ativismo estudantil, a ação parlamentar, as greves operárias e o início da luta armada promovida pela esquerda radical. A força motriz desses eventos tinha raízes internas, mesmo assim há que considerar o impacto do quadro internacional sobre os ativistas de oposição em 1967/68, notadamente as lutas pela independência nos países colonizados e pela revolução socialista no terceiro mundo, com o caso cubano funcionando como poderoso chamariz na América Latina, além do ativismo juvenil nos espaços públicos das grandes metrópoles mundiais, com a sensação de emergência do "poder jovem".

Os eventos dramáticos de 1968 são conhecidos, por isso basta listar os de maior impacto. ${ }^{4}$ Desde 1967 era perceptível o maior ativismo de oposição nos 
movimentos sociais, nas manifestações de rua e na atuação dos políticos tradicionais, tanto no MDB como na Frente Ampla. ${ }^{5}$ Mas em 1968 a temperatura política subiu a níveis bem mais graves, inclusive porque se intensificaram as ações terroristas, de esquerda e de direita. $\mathrm{O}$ ano começou com várias marchas estudantis, sendo que em uma delas foi assassinado o jovem Edson Luís (28 de março de 1968), que se tornou símbolo a inspirar mais protestos liderados por universitários. No calendário desses protestos de rua destacam-se os meses de abril e junho, em que ocorreram episódios extremamente violentos, resultando em muitas mortes (Valle, 2008). A radicalização das lideranças estudantis gerou a ocupação de prédios universitários por todo o país, em protesto contra as políticas da ditadura, levando ao enfrentamento com a polícia e com grupos de direita, a exemplo da chamada Batalha da Maria Antônia, em São Paulo (outubro de 1968). Os operários também se fizeram presentes no cenário com duas greves marcantes, em Contagem (abril de 1968) e em Osasco (julho de 1968), levando os líderes da ditadura a terem pesadelos pelo medo de que os trabalhadores aderissem aos protestos políticos. Ao mesmo tempo, grupos armados de esquerda fizeram ações de "expropriação" para a coleta de fundos e ações terroristas, como a execução de um militar norte-americano (Charles Chandler) e um atentado à bomba a quartel do II Exército. Portanto, ao longo do ano a violência política assumiu proporções intensas e graves, especialmente a praticada pelos órgãos repressivos estatais que, obviamente, tinham maior poder de fogo e mataram ou feriram dezenas de pessoas.

A promessa de diálogo do governo Costa e Silva não resistiu a tais desafios, notadamente em razão da resposta da direita radical ao incremento das ações oposicionistas, provocando uma escalada repressiva por sua vez geradora de mais protestos. Durante a crise a ditadura foi perdendo a confiança de parte de seus apoiadores iniciais, o que é perceptível no noticiário da imprensa. $\mathrm{O}$ governo recebeu muitas críticas da mídia, acusado de incompetência para conduzir o desafiador quadro político. Um dos temas mais abordados era a lentidão do Ministério da Educação para implementar a prometida reforma universitária, considerada essencial por muitos para aplacar a rebeldia dos jovens. ${ }^{6}$ A grande imprensa não gostava da esquerda radical e apoiava a repressão contra o "terrorismo", porém, temia que uma resposta excessivamente violenta do Estado piorasse a situação. Sobretudo, os líderes da grande mídia não confiavam na capacidade do governo Costa e Silva de lidar adequadamente com a crise.

Em meio a tantos eventos críticos e episódios de violência, o discurso do deputado Márcio Moreira Alves (MDB) no dia 3 de setembro de 1968 parece um episódio menor. Moreira Alves era um jovem jornalista que, como muitos 
brasileiros das classes superiores, passou de apoiador do golpe de 1964 a crítico agudo da ditadura. ${ }^{7}$ No seu caso, a trajetória de radicalização à esquerda levou à aproximação com a guerrilha e ao exílio. O discurso do deputado Moreira Alves foi um protesto contra a violência dirigida a estudantes e outros ativistas da oposição, em que aludiu às comemorações de Sete de Setembro. Ele convidou a sociedade a boicotar os desfiles oficiais, e às mulheres, que deixassem de sair e dançar com cadetes e jovens oficiais. Essa é a parte do discurso que se tornou mais célebre e mais lembrada, talvez por seu sabor picante e derrisório.

No entanto, segundo fontes militares, a parte do discurso mais ofensiva às Forças Armadas foi a referência ao Exército como santuário de torturadores: "Quando a polícia não será mais um bando de facínoras; quando o Exército deixará de ser um valhacouto de torturadores?”. Jarbas Passarinho, coronel do Exército e então ministro do Trabalho, registrou em suas memórias que o incômodo maior decorreu da referência aos militares como facínoras e torturadores (Passarinho, 1996, p.312). A versão é confirmada pelos registros da embaixada norte-americana, que não fazem referência "ao boicote das moças", apenas à indignação dos ministros militares por terem sido chamados de torturadores. ${ }^{8}$

De qualquer modo, as críticas do deputado seriam contornáveis em outro contexto, se estivesse em vigor um regime democrático. Não era o caso. Os ministros militares pediram a punição do deputado e o principal líder civil do governo (o ministro da Justiça Gama e Silva) encampou essa demanda, solicitando à Câmara dos Deputados que autorizasse o julgamento de Moreira Alves. A Constituição liberal-autoritária ${ }^{9}$ de 1967 previa a figura clássica da imunidade parlamentar, de maneira que somente com assentimento da Câmara seria possível julgar o deputado. A solicitação do governo criava situação potencialmente explosiva na relação entre Executivo e Legislativo. Embora a maioria dos parlamentares apoiasse a "revolução", a aceitação do pedido implicava abrir mão da autonomia do Congresso, dobrando-se vergonhosamente à vontade do Poder Executivo. Uma vez feito o pedido, a derrota implicaria grave vexame político para o governo, especialmente em situação de crise e perda de apoio. Dada a situação arriscada criada pelo governo, a interpretação sobre a motivação dos autores leva a duas hipóteses principais, não necessariamente excludentes: malícia ou falta de perspicácia. O placar da derrota do governo foi o seguinte: por 216 votos a 141 (e 12 abstenções) os deputados negaram a suspensão da imunidade parlamentar de Márcio Moreira Alves. Para o resultado contribuíram parlamentares do partido oficial, a Arena, que em nome da autonomia do Poder Legislativo votaram contra o seu governo: mais de noventa deputados arenistas 
votaram a favor do parlamentar (Grinberg, 2009, p.125). O episódio representou o ponto mais alto do isolamento político dos militares no poder, que responderam com a edição do AI-5.

O Ato Institucional no 5 conferia ao presidente da República poderes praticamente ilimitados. Embora o primeiro artigo afiançasse a manutenção da Constituição de 1967, nos artigos seguintes ficava evidente que a Carta passava a submeter-se à vontade do Poder Executivo. O presidente poderia fechar as casas parlamentares, cassar mandatos e direitos políticos dos cidadãos, confiscar bens acumulados no exercício de cargos públicos, censurar a imprensa e decretar estado de sítio. Além disso, ficava suspensa a garantia de habeas corpus para crimes políticos, contra a segurança nacional, a ordem econômica e social e a economia popular. Para retomar o expurgo do serviço público iniciado em 1964, mais uma vez foi decretada a suspensão das garantias de vitaliciedade, inamovibilidade e estabilidade. O governo poderia demitir, remover ou aposentar qualquer servidor público, sem necessidade de processo ou inquérito regular.

O caráter draconiano do AI-5 gerou dissensões com aliados da ditadura que preferiam um regime autoritário moderado, compatível com algumas instituições liberais. Como já foi dito, a grande imprensa também recebeu mal a nova inflexão autoritária da ditadura. Além de discordarem da necessidade do novo Ato, os controladores da imprensa não desejavam intensificação da censura, o que ocorreu imediatamente, pois militares e policiais foram despachados para as redações para atuarem como censores. ${ }^{10}$

Outro aliado de primeira hora no golpe de 1964 a discordar do AI-5 foi o governo norte-americano. Aliás, o AI-5 foi um marco nas relações entre a ditadura e os Estados Unidos, cujos representantes no Brasil foram instruídos a aumentarem o diálogo com forças de oposição. A opinião majoritária entre os representantes norte-americanos foi contrária ao AI-5, considerado um lance perigoso e arriscado. Em documento interno do Departamento de Estado, o Secretário Dean Rusk mostrou-se desiludido e preocupado. O desacordo decorria de razões ideológicas, mas, principalmente, de cálculos pragmáticos. A nova situação geraria péssima publicidade nos Estados Unidos e na Europa, criando obstáculos à manutenção de boas relações entre os dois países. Na opinião de Rusk o AI-5 era uma resposta desproporcional ("Costa e Silva and the military overreacted") aos desafios lançados pela oposição e poderia levar o Brasil ao beco sem saída de uma ditadura violenta, com desdobramentos imprevisíveis e perigosos. O pior cenário seria se a ditadura deixasse a oposição sem alternativas, exceto respostas igualmente violentas; com isso, sairiam fortalecidas as forças revolucionárias de esquerda. 
Outro temor assombrava os diplomatas dos Estados Unidos: a possibilidade de que a radicalização da extrema direita militar levasse o regime a uma guinada antiamericana, fenômeno observado em outras partes do mundo. Dado o desconforto em relação ao AI-5, os diplomatas foram instruídos a tentar convencer as autoridades brasileiras a moderar sua ação. A curto prazo, adotaram-se algumas medidas tímidas para mostrar a desaprovação dos Estados Unidos, como o corte de parte da ajuda financeira e o embargo da venda de aviões militares. No entanto, ações críticas mais contundentes contra o governo brasileiro foram evitadas e justificadas com argumentos pragmáticos, ${ }^{11}$ sobretudo após o começo da administração republicana de Richard Nixon, em 1969.

A propósito, os diplomatas norte-americanos no Brasil constituem fonte de informação importante para avaliar o impacto do AI-5 entre setores de elite. Preocupados com os rumos que o governo brasileiro passaria a trilhar e com os eventuais riscos para seus interesses, ao longo de 1969 os diplomatas norte-americanos colheram impressões entre diversos líderes políticos, empresariais e intelectuais. Deve-se ter cuidado ao analisar tais registros, pois podem estar contaminados pela opinião de quem os produziu. Talvez isso explique por que a maioria dos brasileiros consultados mostrasse reservas em relação ao AI-5 e lamentasse o aumento de repressão política. Não obstante, algumas opiniões eram favoráveis à medida, em geral sob o argumento de que iria facilitar os projetos de modernização e a gestão da máquina pública.

Entre as lideranças entrevistadas pelos diplomatas os mais críticos em relação ao AI-5 foram os políticos, inclusive os da Arena. Muitos líderes da situação - desde figuras destacadas como José Sarney e Luiz Vianna Filho a simples vereadores - temeram que os militares passassem a governar sozinhos e dispensassem o seu auxílio. O pessimismo devia-se à percepção de que os militares desprezavam os políticos, por isso mesmo suspenderam temporariamente o funcionamento do Congresso Nacional e de algumas Assembleias Legislativas. Alguns jornalistas e diplomatas brasileiros ouvidos pelos agentes consulares norte-americanos igualmente mostraram-se pessimistas e descontentes, temendo as consequências do aumento da repressão política. Entre intelectuais e pesquisadores acadêmicos, de forma semelhante, o AI-5 gerou medo e ansiedade. Até mesmo alguns militares ouvidos pelos norte-americanos revelaram discordância com o novo Ato, como o almirante Levy Reis e o general da reserva Golbery do Couto e Silva. Golbery, que futuramente seria considerado o "bruxo" da ditadura, achou o AI-5 exagerado e desnecessário, pois o Estado já dispunha de instrumentos suficientes para lidar com a oposição e os subversivos. ${ }^{12}$ 
No entanto, os mesmos militares manifestaram opinião que seria partilhada por muitas lideranças civis: o incremento do poder autoritário poderia trazer benefícios econômicos e favorecer a modernização tecnológica e administrativa. Argumento idêntico foi apresentado por algumas lideranças acadêmicas, que disseram ter esperança de que o novo ciclo autoritário daria mãos livres aos militares para a aplicação de medidas como o aumento de recursos para pesquisas e para as universidades e a implantação efetiva da prometida reforma universitária. Segundo a opinião de destacada liderança acadêmica, se o AI-5 ajudasse a alcançar a reforma universitária estaria justificado. ${ }^{13}$ Com base em opinião semelhante, os líderes empresariais foram o grupo mais entusiasmado em relação ao AI-5. Diretores de entidades de classe como a Confederação Nacional da Indústria (CNI) e a Federação das Indústrias do Estado de São Paulo (Fiesp) manifestaram apoio ao governo. Eles acreditavam que o incremento do poder nas mãos do Poder Executivo iria simplificar decisões na área econômica e retirar obstáculos ao crescimento das atividades produtivas. ${ }^{14}$ Com a subsequente explosão de crescimento econômico no contexto do "milagre" os empresários ficariam ainda mais satisfeitos com a ditadura, embora o aumento do intervencionismo estatal desagradasse a alguns setores.

\section{AfINAL, POR QUE O AI-5?}

Chegamos à parte central do artigo, em que se analisam as razões e motivações do governo Costa e Silva para editar o AI-5, em contraste com seus discursos moderados iniciais. Em primeiro lugar, como fica evidente pela posição dos diplomatas norte-americanos, foi uma decisão com motivações internas. Ao contrário de 1964, quando o apoio do Estado norte-americano serviu de importante incentivo para os golpistas, em 1968 o governo dos Estados Unidos não acompanhou a escalada autoritária. O novo momento significou redução da sua influência sobre a ditadura e mesmo o surgimento de sentimento antiamericano entre alguns oficiais, gerando nos agentes daquele país o temor de uma deriva "nasserista" no Brasil. ${ }^{15}$ Tampouco se pode argumentar, como algumas análises sobre as origens do golpe de 1964 - aliás, por vezes exageradas -, que houvesse necessidade econômica ou novo projeto de acumulação capitalista a impulsionar o AI-5. A motivação principal não foi econômica e sim política. Certo que alguns agentes viram benefícios econômicos no fortalecimento do poder autoritário. Porém, não foi isso que originou os eventos. 
As abordagens historiográficas sobre a crise de 1968 pouco se ocuparam de reflexões sistemáticas sobre as motivações que geraram o AI-5. A maior parte dos trabalhos se dedicou às ações da oposição e dos grupos de resistência, dando destaque às mobilizações contrárias à ditadura ao longo de 1968. Pouca atenção é conferida às opiniões e estratégias dos grupos de direita encastelados no poder, bem como à complexidade da sua composição, suas divergências e a existência de um setor mais aferrado a valores liberais que tentava conter o ímpeto dos defensores do aprofundamento autoritário da "revolução". Os objetivos anunciados pelos autores do AI-5 são questionados, e duvida-se de que a intenção real por trás da escalada autoritária coincidisse com os discursos dos golpistas. Porém, parece-me que falta analisar com mais cuidado as motivações dos agentes autoritários. ${ }^{16}$ Se as razões reais não foram aquelas enunciadas, quais foram?

Para iniciar a análise, vamos levar em consideração os argumentos apresentados pelos autores e defensores do AI-5. Obviamente, há que manter o espírito crítico e duvidar das versões apresentadas pelos agentes históricos. Porém, não é o melhor caminho descartá-las de imediato como pura falsidade ou manipulação. Melhor é analisá-las para distinguir em que medida foram efetivamente inspiradoras para os agentes - considerando que muitas vezes a ação política é motivada por percepção distorcida ou equivocada da realidade, em razão da força da paixão ou do interesse - e em que medida foram fruto de manipulação e oportunismo.

Um ponto de partida é o texto do próprio AI-5, que em sua parte inicial apresentou justificativas para o novo Ato. O texto afirmou o compromisso de preservar a "Revolução" e seus objetivos, que seriam assegurar "autêntica ordem democrática, baseada na liberdade, no respeito à dignidade da pessoa humana, no combate à subversão e às ideologias contrárias às tradições de nosso povo, na luta contra a corrupção". Ainda segundo o texto introdutório do AI-5, "atos nitidamente subversivos, oriundos dos mais distintos setores políticos e culturais, comprovam que os instrumentos jurídicos, que a Revolução vitoriosa outorgou à Nação para sua defesa, desenvolvimento e bem-estar de seu povo, estão servindo de meios para combatê-la e destruí-la". De acordo com os autores do AI-5, os ideais do regime político instaurado em 1964 estariam comprometidos "por processos subversivos e de guerra revolucionária”, daí a necessidade de editar o novo Ato Institucional. ${ }^{17}$

Outra fonte para captar as justificativas dos defensores do AI-5 são os arquivos diplomáticos norte-americanos. Além de lideranças com opiniões críticas em relação ao novo ato autoritário, os diplomatas ouviram também 
figuras favoráveis. No dia 20 de dezembro de 1968, o embaixador John Tuthill enviou a Washington telegrama relatando alguns encontros com líderes brasileiros favoráveis ao AI-5, oficiais militares, membros do governo e "extremistas civis". ${ }^{18}$ Sabendo que a opinião norte-americana era negativa e temendo perder o seu apoio, tais figuras tentaram convencer os antigos aliados da justeza do AI-5. As lideranças que procuraram os diplomatas dos Estados Unidos usaram os mesmos argumentos constantes no texto do Ato, porém, exploraram-nos em mais detalhe e acrescentaram outros temores dos grupos de direita. Com base em tais conversas Tuthill fez uma síntese das justificativas apresentadas para o AI-5, registrando alguns aspectos pouco considerados nas análises sobre o tema.

Os pontos mais enfatizados pelos visitantes do embaixador, previsivelmente, foram a subversão e os riscos para a ordem. O objetivo de combater a corrupção foi alegado também, mas de maneira secundária em relação às ameaças políticas. ${ }^{19}$ Os interlocutores direitistas falaram do desafio estudantil e das ações armadas da esquerda como problemas graves, destacando que alguns religiosos e artistas apoiavam tais ações radicais. O risco não estava apenas nas ações armadas em si, mas, no desprestígio que traziam para o governo, que sabia da sua impopularidade. Ademais, o fato de as autoridades judiciais libertarem ativistas radicais de esquerda era considerado também problema sério, pois serviria de incentivo para tais grupos. Significativamente, no dia anterior à votação fatídica na Câmara dos Deputados a justiça federal determinou a libertação de cerca de oitenta estudantes detidos pelas forças de repressão nos meses anteriores, entre eles as mais importantes lideranças do grupo.

Ainda no campo das justificativas políticas, as fontes do embaixador Tuthill mencionaram uma perspectiva pouco citada nas interpretações sobre os efeitos da derrota do governo no caso Moreira Alves. Preocupava não apenas a derrota nesse episódio específico, mas que ela abrisse caminho para novos desafios parlamentares ao governo, como a eventual aprovação de anistia aos punidos pela ditadura e possível tentativa de restabelecer eleições diretas para presidente. Ademais, os militares ficaram irritados com a ousadia de deputados de oposição que tentaram convocar para depoimento na Câmara alguns generais líderes do setor de segurança como E. Médici e Portella de Mello. Ou seja, parte da motivação para o AI-5 era enquadrar autoritariamente o Congresso, evitando que se tornasse um foco de oposição ao governo militar.

Finalmente, vale a pena destacar outros dois temas captados por Tuthill nas conversas. Primeiro, o AI-5 foi também motivado por frustrações militares de natureza corporativa, como baixos soldos e carência de investimentos e de 
equipamentos nas Forças Armadas. ${ }^{20}$ Segundo ponto, mais relevante por trazer perspectiva original sobre a opinião dos golpistas de 1968: um dos motivos para a escalada autoritária era revigorar o governo Costa e Silva e o ânimo dos "revolucionários", fortalecendo-os para que os objetivos de 1964 fossem alcançados. O embaixador percebeu que segmentos do governo e parte de seus apoiadores radicais concordaram com as críticas da oposição sobre a ineficiência e incompetência da gestão Costa e Silva. Líderes direitistas criticaram pessoalmente o presidente por desatenção em face dos graves problemas enfrentados pelo governo e o país. Portanto, o AI-5 teria também como propósito revigorar o governo e corrigir os seus rumos.

No final do relato, Tuthill concluiu que seus interlocutores pareciam sinceros e acreditavam realmente na existência de desafios políticos graves ao governo. No entanto, achou a avaliação equivocada, pois, mesmo na hipótese improvável de união entre todas as forças de oposição, ainda não seriam suficientes para derrubar o governo. Na visão do embaixador, os motivos apresentados por seus interlocutores mostravam uma soma de frustrações acumuladas desde 1964, com a derrota no Congresso funcionando como última gota. Ainda assim, o AI-5 não seria opção razoável, pois o governo já dispunha de instrumentos suficientes para enfrentar todos os desafios.

Outro registro nos arquivos norte-americanos com informações úteis para avaliar as origens do AI-5 é o relato da conversa com Golbery do Couto e Silva, em que este declarou sua discordância com o novo Ato, embora vislumbrasse alguns pontos positivos. Afastado do governo na gestão de Costa e Silva e considerado persona non grata pelo novo grupo no poder, mesmo assim Golbery acompanhava os acontecimentos. Em sua opinião o AI-5 foi medida desnecessária e exagerada, fruto de incompetência, maquiavelismo e anticomunismo extremos. De incompetência eram acusados Costa e Silva e parte do ministério, sobretudo Tarso Dutra (ministro da Educação) e Gama e Silva, enquanto o maquiavelismo era atribuído a alguns chefes militares e civis que apostaram no impasse com o Congresso, como o próprio Gama e Silva. Ainda segundo Golbery, o anticomunismo radical mobilizou muitos chefes militares, em especial um grupo de generais em comandos importantes (Antônio Carlos Muricy, Augusto César Muniz de Aragão, João Dutra de Castilho, Sylvio Frota, Ramiro Gonçalves Tavares e Sizeno Sarmento), com o apoio de alguns coronéis. Esses oficiais identificavam uma guerra revolucionária em curso cuja derrota demandava instrumentos repressivos excepcionais. Golbery achava essa avaliação muito exagerada e estava pessimista em relação aos desdobramentos políticos futuros, porém, esperava que algumas reformas andassem 
mais rápido, pois os militares não se opunham à modernização das universidades e a mudanças na estrutura agrária, por exemplo, ao contrário de outros apoiadores da ditadura. ${ }^{21}$

Com os dados disponíveis, retirados tanto das fontes primárias como da literatura acadêmica, é possível empreender análise interpretativa sobre as principais motivações para a edição do AI-5. Em primeiro lugar, reiterando, o motor foi interno, desta feita não houve apoio internacional à escalada autoritária, ao contrário. O fator externo mais relevante foi o temor da direita em relação à radicalização dos jovens e dos revolucionários em escala global e continental, inclusive o medo do apoio cubano aos guerrilheiros. Em segundo lugar, os fatores econômicos tiveram peso pouco significativo, já que os indicadores eram positivos e estava para se iniciar o grande salto de crescimento. Alguns agentes - empresários, tecnocratas e militares - acreditaram que o aumento do poder estatal traria vantagens econômicas e agilizaria o projeto de modernização autoritária, porém, tratou-se mais de argumento compensatório, um ganho lateral, do que o motor principal do AI-5. Afinal, os agentes centrais do novo golpe eram militares e, para muitos deles, a economia era tema secundário. A motivação principal foi política, e os promotores do Ato eram militares obcecados com a manutenção da ordem e o combate à esquerda revolucionária, contando com apoio da extrema-direita civil.

Portanto, a direita militar - e seus aliados civis - desempenhou papel chave nos acontecimentos, principalmente para gerar a pressão necessária para que o novo Ato Institucional fosse editado. Tais grupos desejavam novos instrumentos de exceção para reprimir a esquerda e completar a "limpeza" iniciada em 1964 que, na sua visão, havia sido interrompida antes do sucesso completo. O retorno da esquerda à cena pública em 1968 tornou tal opinião muito forte entre a direita radical, que se armou de ânimo - e de ódio - para terminar o serviço começado em 1964. Como registrou Tuthill, não se deve duvidar da sinceridade desses grupos e, tampouco, devemos subestimar a força dos protestos de rua e dos conflitos de 1968, que causaram grande ansiedade à direita. Pressionado e com seu prestígio abalado, o governo Costa e Silva cogitara decretar estado de sítio ou um novo Ato Institucional em diferentes ocasiões ao longo de 1968. De fato, um cenário inquietante para a direita radical se descortinou ao longo de 1968, e ela acreditou ter justificados motivos para demandar mais dureza da parte do governo.

No entanto, mesmo que do ponto de vista da direita o cenário fosse desafiador, existiam instrumentos suficientes para manter a ordem, sem necessidade de novas medidas de exceção. Ou melhor - e aí está um detalhe e uma 
chave de análise fundamental -, o Estado possuía meios suficientes para lidar com os desafios provenientes da esquerda. Porém, não dispunha de meios suficientes para enquadrar e disciplinar segmentos rebeldes da própria elite situados em lugares estratégicos, como o Poder Legislativo, o Poder Judiciário e a imprensa. A ditadura legada por Castelo Branco oferecia recursos de sobra para reprimir os revolucionários de esquerda, entretanto, ela garantia também alguns espaços de atuação para dissidentes moderados, graças à manutenção de algumas instituições liberais.

Assim, o AI-5 era uma resposta para lidar com tal "problema", permitindo ao Estado cassar mandatos parlamentares e aposentar servidores públicos incômodos para o governo, como os juízes que impediam a "justiça revolucionária" de agir livremente, ou os professores universitários acusados de estimular a rebeldia estudantil. Além disso, a escalada autoritária tinha a vantagem de livrar o governo da necessidade de negociar com as lideranças políticas e o Congresso, ficando com as mãos livres para implantar as medidas de sua preferência. No mesmo sentido, o AI-5 permitia censurar as críticas publicadas pela imprensa contra o governo, inclusive na grande mídia, que até então se mantivera a salvo da repressão. Portanto, os alvos do novo ato autoritário não estavam apenas à esquerda, como é mais frequentemente notado. O AI-5 visava também, e sobretudo, enquadrar os segmentos da elite que se mostravam rebeldes ao poder militar.

Em momento de crescente impopularidade e perda de apoio de grupos que sustentaram o golpe de 1964 como a imprensa, o Judiciário, a Igreja, as classes médias e a elite parlamentar, o governo Costa e Silva adotou o imprudente gesto de solicitar ao Congresso licença para processar Moreira Alves. Ação imprudente? Talvez maliciosa. O responsável pelo pedido, o ministro da Justiça Gama e Silva, pode ter feito uma jogada oportunista, apostando no impasse institucional para justificar a escalada autoritária. Mas não se pode descartar inteiramente a hipótese de imprudência e falta de visão política. Sabe-se, com certeza, que ele cortejava a direita militar e desejava associar-se a ela, talvez mais por oportunismo do que por convicções ideológicas. No entanto, é significativo registrar que, após o governo Costa e Silva, Gama e Silva saiu do cenário político principal ao ser nomeado embaixador em Portugal, não ocupando mais lugar de proeminência nos governos militares. Apesar de sua atuação em favor do endurecimento da ditadura militar e da edição do AI-5, ele não teve novas oportunidades em sua carreira política.

Seja como for, a derrota do governo Costa e Silva na votação da Câmara gerou efetivamente situação grave. Os deputados arenistas que votaram contra 
o governo não estavam renegando a "revolução", mas mostraram que o poder do governo tinha limites. Mostraram também, pelo seu gesto, preferirem um tipo de ditadura que respeitasse o compromisso, embora precário, com as instituições políticas liberais, que a seus olhos poderiam ser controladas, mas não subjugadas. A decisão da Câmara foi uma amostra clara do desprestígio do governo Costa e Silva, gerando situação de impasse. Caso fosse um governo democrático, liderado por figuras afeitas ao jogo parlamentar, a crise seria contornável. Mas tratava-se de uma ditadura, comandada por militares, homens acostumados à autoridade vertical. Verdade que essa ditadura tinha limites e tentava compatibilizar o poder militar com as instituições liberais que, embora limitadas e manietadas, estavam em funcionamento. No entanto, os militares em comando aceitavam esse jogo apenas enquanto sua vontade prevalecesse; não estavam dispostos a ter seu poder desafiado. A situação era ainda mais complexa porque o governo Costa e Silva estava enfraquecido em razão da perda de aliados civis e da pressão dos quartéis.

Tendo em vista esse quadro fica mais fácil entender a decisão de editar o AI-5. Pode ser mesmo que, no seu íntimo, Costa e Silva não gostasse da ideia, inclusive por não desejar passar à história como responsável por agravar a ditadura. Porém, seu governo poderia não durar muito caso não aceitasse o novo Ato. Como afirmou o editorial de O Estado de S. Paulo do dia 13 de dezembro de 1968, o que provocou o recolhimento da edição pelos militares, após a votação da Câmara o regime estava por um fio. Para não cair, o governo aceitou a demanda dos grupos radicais que desejavam "salvar a revolução". ${ }^{22}$ Pressionado à esquerda e à direita, com suas bases de apoio esgarçadas, não podendo contar com seu próprio partido, o governo Costa e Silva respondeu com a dureza do AI-5. Um ato de força praticado por um governo fraco. Dizia querer salvar a "revolução", mas estava salvando principalmente seu próprio governo. Sentindo-se sem apoio no sistema político, na imprensa e na intelectualidade, sua opção foi aceitar as demandas dos setores repressivos e entregar mais poder às Forças Armadas, passando a escorar-se quase que exclusivamente na caserna.

Com o AI-5 os grupos mais à direita (conservadores, nacionalistas, fascistas) reagruparam-se em torno do governo, aproveitando a situação para aumentar seu poder e sair à caça dos inimigos. De maneira semelhante, a corporação militar alinhou-se mais estreitamente à "revolução", que se tornou mais do que nunca obra das Forças Armadas. Agora donos incontestes do poder, os militares poderiam ter suas demandas mais bem atendidas, inclusive as corporativas. É verdade que os protagonistas do AI-5 foram militares 
alinhados à direita radical naquele momento, mas sua ação acabou unindo os outros segmentos da caserna em defesa do regime, mesmo que com ressalvas em alguns casos. Ainda assim, permaneceram disputas pelo poder e pelo controle do processo de expurgo, com grupos da direita radical questionando o comando de Costa e Silva, enquanto este labutava para evitar que tais setores ganhassem demasiada autonomia. ${ }^{23}$

Já os aliados (ou ex-aliados) liberais da ditadura na imprensa, na intelectualidade e na elite política retraíram-se, inclusive porque alguns deles eram alvos da direita radical e foram presos temporariamente, para amedrontar. Quando as coisas se acalmaram eles voltaram à cena, fazendo pressão discreta para que a ditadura moderasse o uso da repressão e buscasse uma normalização política. ${ }^{24}$ Quanto aos homens de negócio e aos tecnocratas, esses aproveitaram o poder discricionário para acelerar os projetos de crescimento e modernização econômica. Na visão desses grupos, o AI-5 e outras medidas autoritárias subsequentes beneficiaram os projetos de expansão econômica por duas razões básicas: primeiro, por forçarem os descontentes ao silêncio, especialmente os que não ganhavam com o "milagre"; segundo, por retirarem de cena o Congresso Nacional, que poderia atrapalhar os projetos de aceleração econômica ou, ao menos, demandar negociações e ajustes que implicariam ritmo mais lento.

Em suma, as motivações a impulsionar o AI-5 podem ser sintetizadas nos seguintes pontos, sem intenção de atribuir a qualquer deles o papel de variável independente, ou seja, de fator determinante principal: a insegurança de grupos de direita militares e civis frente ao aumento do ativismo da oposição no parlamento, nas ruas e nas ações de resistência armada da esquerda, que a seus olhos ameaçava o regime; associada ao último ponto, a intenção dos mesmos setores de golpear as instituições liberais para retirar os limites que tolhiam sua ânsia repressiva; a perda de prestígio do governo militar entre segmentos dominantes, sobretudo a imprensa, o Judiciário, o Parlamento, a Igreja e as elites sociais, gerando sensação de isolamento e de fragilidade; o projeto de revigorar a "revolução" através da escalada autoritária, uma ofensiva imaginada como uma espécie de retorno às fontes originais de 1964, tendo em vista também unificar as Forças Armadas na defesa do regime.

A novidade do argumento é destacar que a perda de prestígio e a sensação de isolamento da ditadura estimularam resposta autoritária de agentes militares com apoio de civis de direita (sobretudo empresários, proprietários rurais e lideranças religiosas conservadoras). O AI-5 foi uma ação para reerguer um governo fraco (Costa e Silva) e revigorar o regime autoritário a que ele 
pertencia, estreitando laços entre os diferentes grupos que compunham a caserna, superando momentaneamente suas dissensões internas. Sobretudo, a principal contribuição desta análise é ressaltar que o Ato Institucional de 13 de dezembro de 1968 teve como alvos privilegiados setores de elite que apoiaram 1964, mas se distanciaram da ditadura no momento seguinte.

O AI-5 forneceu ao Estado meios para punir e enquadrar lideranças e segmentos rebeldes do seu próprio campo, como parlamentares, juízes e a imprensa. Significativamente, alguns deles só então começaram a perceber aquele regime político como uma ditadura, tendo passado ao campo da oposição ou se tornado apoiadores críticos do regime militar. No contexto do processo de abertura construiu-se a versão de que sempre haviam lutado contra o autoritarismo e a favor da democracia, uma tentativa de apagar sua responsabilidade como aliados de primeira hora do golpe de 1964 e da ditadura.

\section{REFERÊNCIAS}

CATROGA, Fernando. Os passos do homem como restolho do tempo: memória e fim do fim da história. Lisboa: Almedina, 2009.

CHIRIO, Maud. A política nos quartéis: revoltas e protestos de oficiais na ditadura militar brasileira. Rio de Janeiro: Zahar, 2012.

CODATO, Adriano. O golpe de 1964 e o regime de 1968: aspectos conjunturais e variáveis históricas. História - Questões \& Debates, Curitiba, n.40, p.11-36, 2004.

GARCIA, Marco Aurélio; VIEIRA, Maria Alice (Org.) Rebeldes e contestadores: 1968, Brasil/França/Alemanha. 2.ed. São Paulo: Ed. Fundação Perseu Abramo, 2008.

GASPARI, Elio. A ditadura envergonhada. São Paulo: Companhia das Letras, 2002.

GRINBERG, Lúcia. Partido político ou bode expiatório: um estudo sobre a Aliança Renovadora Nacional (Arena), 1965-1979. Rio de Janeiro: Mauad X, 2009.

KUSHNIR, Beatriz. Cães de guarda: jornalistas e censores, do AI5 à Constituição de 1988. São Paulo: Boitempo, 2004.

MARTINS FILHO, João Roberto. O palácio e a caserna: a dinâmica militar das crises políticas na ditadura (1964-1969). São Carlos, Ed. UFSCar, 1995.

Rebelião estudantil: 1968 - México, França e Brasil. Campinas: Mercado das Letras, 1996.

MELLO, Jayme Portella de. A Revolução e o governo Costa e Silva. Rio de Janeiro: Guavira, 1979.

MOREIRA ALVES, Márcio. Torturas e torturados. Rio de Janeiro: Idade Nova, 1966. . A velha classe. Rio de Janeiro: Arte Nova, 1964. 
MOTTA, Rodrigo Patto Sá. Entre a liberdade e a ordem: o jornal O Estado de S. Paulo e a ditadura (1969-1973). Estudos Ibero-Americanos, Porto Alegre, v.43, n.2, p.367379, maio/ago. 2017.

. Em guarda contra o perigo vermelho: o anticomunismo no Brasil (1917-1964). São Paulo: Perspectiva; Fapesp, 2002. . As universidades e o regime militar. Rio de Janeiro: Jorge Zahar, 2014.

NAPOLITANO, Marcos. 1964: História do regime militar brasileiro. São Paulo, Contexto, 2014.

PASSARINHO, Jarbas. Um híbrido fértil. Rio de Janeiro: Expressão e Cultura, 1996.

PERRONE, Fernando. 68, relatos de guerra: Praga, São Paulo, Paris. São Paulo: Busca Vida, 1988.

RICOEUR, Paul. A memória, a história, o esquecimento. Campinas: Ed. Unicamp, 2007. REIS FILHO, Daniel Aarão. Ditadura e sociedade: as reconstruções da memória. In: REIS FILHO, Daniel Aarão; RIDENTI, Marcelo; MOTTA, Rodrigo Patto Sá. O golpe e a ditadura militar, 40 anos depois (1964-2004). Bauru: Edusc, 2004.

REIS FILHO, Daniel Aarão; MORAES, Pedro de. 68: a paixão de uma utopia. 2.ed. Rio de Janeiro: Ed. FGV, 1998.

RIDENTI, Marcelo. Breve recapitulação de 1968 no Brasil. In: GARCIA, Marco Aurélio; VIEIRA, Maria Alice (Org.) Rebeldes e contestadores: 1968, Brasil/França/Alemanha. 2.ed. São Paulo: Ed. Fundação Perseu Abramo, 2008. p.55-60.

. O fantasma da revolução brasileira. São Paulo: Ed. Unesp; Fapesp, 1993.

SETEMY, Adrianna C. L. E defesa da moral e dos bons costumes: a censura de periódicos no regime militar (1964-1985). Dissertação (Mestrado em História) - Universidade Federal do Rio de Janeiro (UFRJ). Rio de Janeiro, 2008.

SKIDMORE, Thomas. Brasil: de Castelo a Tancredo. Rio de Janeiro: Paz e Terra, 1988. STEPAN, Alfred. Os militares na política. Rio de Janeiro: Artenova, 1975.

VALLE, Maria Ribeiro do. 1968: o diálogo é a violência. Movimento estudantil e ditadura militar no Brasil. Campinas: Ed. Unicamp, 2008.

VELASCO E CRUZ, Sebastião. Significados da conjuntura de 1968. In: GARCIA, Marco Aurélio; VIEIRA, Maria Alice (Org.) Rebeldes e contestadores: 1968, Brasil/França/Alemanha. 2.ed. São Paulo: Ed. Fundação Perseu Abramo, 2008. p.105-110.

VENTURA, Zuenir. 1968, o ano que não terminou. Rio de Janeiro: Nova Fronteira, 1988.

ZAPPA, Regina; SOTO, Ernesto. 1968: eles só queriam mudar o mundo. Rio de Janeiro: Jorge Zahar, 2008.

\section{NOTAS}

${ }^{1}$ Concordamos com RICOEUR (2007, p.193-198) e CATROGA (2009, p.116-119) quando sugerem evitar uma dicotomia entre o método compreensivo e a explicação científica tra- 
dicional. A distinção entre explicar e compreender não é tão aguda como já se imaginou, pois, muitas vezes a operação historiográfica empreende os dois movimentos ao mesmo tempo.

${ }^{2}$ Em um desses documentos, o Chargé d'Affaires da Embaixada norte-americana resumiu o ponto de vista dos agentes do seu país sobre o então futuro presidente Costa e Silva (em 21 jun. 1966): ele era inexperiente em assuntos políticos e econômicos, bem como tinha ligações sociais e políticas pouco confiáveis. Além disso, a política econômica vigente até então (e que era do gosto dos Estados Unidos) poderia ter seus rumos alterados. RG 59, caixa1938, pasta 1. National Archives and Records Administration (NARA II). Observação: os documentos do governo norte-americano citados neste artigo serão disponibilizados no site do Laboratório de História do Tempo Presente da UFMG.

${ }^{3}$ Aqui nos referimos ao liberalismo de matriz política, notadamente aos setores influenciados pela UDN que apoiaram o golpe em nome da defesa das instituições liberais contra as ameaças "caudilhistas" e "comunizantes". Esses personagens podiam ser encontrados não apenas no sistema político, mas também na imprensa, na intelectualidade, no mundo empresarial e no judiciário. Outra fonte a influenciar tais posições liberais foram as agências e a diplomacia norte-americanas. Esses setores apoiaram a intervenção autoritária, aparentemente contrariando seus ideais, mas, ao mesmo tempo, desejavam que o novo regime político se mantivesse no leito das instituições liberais tanto quanto possível, ressalvada a prioridade de reprimir os inimigos revolucionários. Daí as tensões - e eventuais conflitos - em relação à ditadura sempre que esses "liberais" percebiam que o autoritarismo se incrementava para além dos limites desejáveis.

${ }^{4}$ Além disso, uma relação completa ocuparia espaço excessivo para um artigo. Uma cronologia detalhada dos eventos pode ser encontrada em REIS FILHO e MORAES (1998) e em ZAPPA e SOTO (2008).

${ }^{5}$ Foi um acordo envolvendo algumas das maiores lideranças políticas do país, que aproximou Carlos Lacerda (ex-apoiador do golpe de 1964) a Juscelino Kubitschek e ao presidente derrubado João Goulart. O caráter inusitado do acordo gerou celeuma entre setores da oposição, porém, a ditadura não queria correr riscos e proibiu a Frente Ampla no início de 1968.

${ }^{6}$ Ver, por exemplo, os seguintes editoriais de O Globo: "Indecisão na cúpula" (12 abr. 1968) e "Reforma da reforma" (28 jun. 1968).

${ }^{7}$ A posição de Moreira Alves em 1964 é visível em seus artigos jornalísticos, que foram reunidos em livro (MOREIRA ALVES, 1964).

${ }^{8}$ RG 59, caixa 1906, pasta 2. National Archives and Records Administration (doravante NARA II).

${ }^{9} \mathrm{O}$ uso dessa expressão decorre da constatação de que o regime político erigido a partir de 1964 representava um compromisso entre diferentes grupos de direita, desde conservadores tradicionalistas a integralistas, desde nacionalistas autoritários a liberais. A Constituição de 1967 resultou desse compromisso, pois, ao mesmo passo em que ampliou os pode- 
res do Executivo e instituiu eleições indiretas para presidente e governadores (além de alguns prefeitos), também manteve prerrogativas do constitucionalismo liberal como a divisão dos poderes, o sistema parlamentar baseado no sufrágio, as garantias individuais clássicas e o judiciário independente. Normalmente se considera que essas características da ditadura representavam apenas uma fachada legal, uma estratégia de legitimação que não implicava efetivo respeito aos textos legais, o que em parte é verdade. No entanto, em certos momentos elas funcionaram também como limites ao poder arbitrário, causando inclusive irritação nos grupos mais à direita, que apoiaram o AI-5 exatamente para suprimir as garantias liberais ainda existentes na Carta de 1967. Estas reflexões, aqui apresentadas de maneira sumária, serão aprofundadas em outro trabalho.

${ }^{10}$ Sobre a censura à imprensa ver KUSHNIR (2004, p.192-207) e SETEMY (2008).

${ }^{11} \mathrm{O}$ pragmatismo era justificado com este argumento: se os Estados Unidos rompessem com o Brasil o quadro poderia piorar, pois eles exerceriam uma suposta pressão moderadora. Telegrama de Rusk enviado à embaixada em 19 dez. 1968. RG 59, caixa 1900, pasta 1. NARA II. Há outros documentos na mesma pasta sobre as reações dos Estados Unidos ao AI-5.

${ }^{12}$ As avaliações sobre as opiniões das lideranças políticas encontram-se na pasta 1 da caixa 1908; as opiniões dos diplomatas encontram-se na caixa 1902, pasta 4; e as referências às opiniões de intelectuais acadêmicos na caixa 1910, pasta 2. Os documentos referentes a Levy Reis e Couto e Silva encontram-se, respectivamente, na caixa 1901, pasta 5 e caixa 1910, pasta 1 (RG 59. NARA II). A entrevista de Couto e Silva contém outras informações interessantes e será retomada logo adiante.

${ }^{13}$ Cf. Caixa 1900, pasta 2, RG 59. NARA II.

${ }^{14}$ Em 18 dez. 1968 a CNI enviou a Costa e Silva um telegrama de apoio ao AI-5, enquanto o presidente da Fiesp fez declarações públicas de mesmo teor. Cf. RG 59, caixa 1910, pasta 1 e caixa 1900, pasta 2. NARA II.

${ }^{15}$ Cf. Caixa 1907, pasta 1, RG 59. NARA II.

${ }^{16}$ Cientistas políticos têm sido os pesquisadores mais interessados em refletir sobre as origens do AI-5, com destaque para MARTINS FILHO (1995) e CODATO (2004). Reflexões de ambos foram incorporadas ao texto, notadamente o questionamento da visão dicotômica sobre dois grupos militares coesos (duros x moderados/castelistas) cuja disputa pelo poder teria contribuído para o AI-5; e a percepção de que o AI-5 foi antes um fator de união do que de desunião dos militares. No entanto, o eixo analítico desenvolvido neste artigo segue caminhos diferentes, de certa maneira explorando e aprofundando insights elaborados por autores como REIS FILHO (2004, p.41) e VELASCO E CRUZ (2008, p.105), que já haviam chamado atenção para a necessidade de considerar o AI-5 uma ação contra dissidentes no próprio campo de apoio à ditadura.

${ }^{17}$ Os trechos entre aspas são excertos da parte introdutória do AI-5.

${ }^{18}$ Cf. RG 59, caixa 1910, pasta 1. NARA II.

${ }^{19}$ Idem. Ainda assim, alguns interlocutores radicais do embaixador Tuthill demonstraram 
empenho em limpar o país da corrupção, mencionando inclusive casos na família do presidente Costa e Silva.

${ }^{20} \mathrm{O}$ tema da insatisfação corporativa como integrante do contexto que levou ao AI-5 é mencionado desde os anos 1970, por exemplo nos trabalhos de STEPAN (1975) e SKIDMORE (1988, p.161).

${ }^{21}$ RG 59, caixa 1910, pasta 1. NARA II.

${ }^{22}$ Várias fontes apontam que Costa e Silva foi pressionado por setores militares a decretar o AI-5, sob o risco de perder o poder. A esse respeito conferir VENTURA (1988, p.265269) e MELLO (1979, p.640-650). Em conversa com diplomatas norte-americanos em abril de 1969, Roberto Campos declarou que Costa e Silva só não caiu porque não havia candidato alternativo forte entre os militares. RG 59, caixa 1910, pasta 2. NARA II.

${ }^{23}$ Afirmação baseada em registros de diplomatas norte-americanos a partir de entrevistas com membros da direita radical e com civis de linha mais moderada. Caixa 1910, pastas 1 e 2. NARA II.

${ }^{24}$ Um exemplo foi a estratégia desenvolvida pelo jornal O Estado de S. Paulo a partir de 1968. Ver MOTTA, 2017.

Artigo recebido em 18 de abril de 2018.

Aprovado em 5 de agosto de 2018.

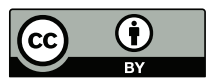

